\title{
Relative susceptibility of peach rootstocks to crown gall and Phytophthora root and crown rot in Chile
}

\author{
Gonzalo Guzmán ${ }^{1}$, Bernardo A. Latorre ${ }^{1}$, René Torres ${ }^{1}$, and Wayne F. Wilcox ${ }^{2}$ \\ ${ }^{1}$ Facultad de Agronomía e Ingeniería Forestal, Pontificia Universidad Católica de Chile, \\ Casilla 306-22, Santiago, Chile. \\ ${ }^{2}$ Department of Plant Pathology, N.Y. State Agricultural Experiment Station, \\ Cornell University, Geneva NY
}

\begin{abstract}
G. Guzmán, B.A. Latorre, R. Torres, and W.F. Wilcox. 2007. Relative susceptibility of peach rootstocks to crown gall and Phytophthora root and crown rot in Chile. Cien. Inv. Agr. 34(1):31-40. Crown gall (Agrobacterium tumefaciens) and Phytophthora root and crown rot (PRCR), caused by P. cryptogea, are two major limiting factors affecting peach (Prunus persica) production in Chile. At present, Nemaguard is the most important rootstock used in peach orchards, and although several clonal rootstocks are under development worldwide, there is little information regarding their susceptibility to crown gall and PRCR. Therefore this investigation was undertaken to study the susceptibility to A. tumefaciens and $P$. cryptogea of the clonally propagated rootstocks Cadman ${ }^{\circledR}$-Avimag ( $P$. persica $x$ P. davidiana), Mr.S $2 / 5$ (P. cerasifera $x$ P. spinosa), Viking ([P. persica $x$ P. davidiana $] x[P$. dulcis 'Jordanolo' $x$ $P$. blireiana $]$ ), and Nemaguard (P. persica $x$ P. davidiana), a seedling rootstock, which was included as a reference standard. Based on our results, Mr.S 2/5 was highly resistant to A. tumefaciens. Differences among Nemaguard, Viking and Cadman grown for 20 months in artifically-infested soil were not statistically significant, but only Cadman developed crown gall in soil with natural levels of inoculum. The extent of the canker lesions produced by $P$. cryptogea on excised twigs of each rootstock was greater on actively growing twigs than on dormant twigs. However, differences among rootstocks determined with the dormant twig assay correlated better with the results following trunk inoculations of 2-yr-old plants budded with 'Ruby Diamond' peach. For all rootstocks, PRCR severity increased considerably after repeated soil saturation episodes, and the loss of root mass increased in a linear manner as the saturation periods increased from 0 to $144 \mathrm{~h}$. Our results showed that Mr.S 2/5 is relatively resistant to root rot caused by $P$. cryptogea, which is the most common Phytophthora species presently found on peach trees in Chile.
\end{abstract}

Key words: Agrobacterium tumefaciens, disease control, nectarines, Phytophthora cryptogea, Prunus spp., rootstock resistance.

\section{Introduction}

Crown gall (Agrobacterium tumefaciens (E.F. Smith and Town) Conn.) and Phytophthora root and crown rot (PRCR), caused by Phytophthora cryptogea Pethybridge and Laffery (Guzmán et al., 2005), are two major limiting factors affecting peach (Prunus persica (L.) Batsch) production in Chile, and often start during

Received 27 September 2006. Accepted 19 January 2007

${ }^{1}$ Corresponding author: blatorre@uc.cl plant propagation at the nurseries. Crown gall is exclusively initiated by wounds created during cultivation practices, whereas PRCR is not dependent on wounded host tissues. Repeated soil saturation periods consistently have been found to be highly favorable to the development of PRCR caused by various species of Phytophthora on annual and perennial crops (e.g., Browne and Mircetich. 1995; Haygood et al., 1986; Latorre, 2004; Matheron and Mircetich, 1985a; Mircetich and Keil, 1970; Wilcox and Ellis, 1989; Wilcox and Mircetich, 1985a). 
Use of resistant rootstock is one of the main strategies suggested to control these two diseases on peach and other fruit crops. At present, Nemaguard (P. persica $\times$ P. davidiana), a relatively vigorous seedling rootstock, is typically used for peach propagation in Chile. It is resistant to root knot nematodes (Meloidogyne spp.) but relatively susceptible to root-lesion nematodes (Pratylenchus spp.), crown gall and PRCR (Dosier et al., 1984). Interspecific hybridization among plums and between plum and peach has been developed, resulting in several new clonal rootstocks for peach that have been introduced commercially in recent years (Renaud et al. 1988). However, there is only limited information regarding the susceptibility of these rootstocks to crown gall and PRCR (Bliss et al. 1999; Thomidis, 2000b; Zoina, and Raio. 1999). Therefore, this investigation was undertaken to evaluate the clonal response of new peach rootstocks to $A$. tumefaciens and P. cryptogea.

\section{Materials and methods}

\section{Location}

All field experiments were performed in Pirque, Santiago (Metropolitan Region), characterized by Mediterranean weather conditions (Novoa and Villaseca, 1989).

\section{Inoculum and plant material}

Phytophthora cryptogea, isolate DZ3, and A. tumefaciens, isolate AD-1, isolated from peach orchard in Chile (Guzmán et al., 2005) were used to evaluate the relative susceptibility of the clonally propagated rootstocks: Cadman ${ }^{\circledR}$ Avimag ( $P$. persica $x$ P. davidiana), Mr.S 2/5 $(P$. cerasifera $x$ P. spinosa) and Viking ([P. persica $x P$. davidiana $] x[P$. dulcis 'Jordanolo' $x$ P. blireiana $]$ ). Nemaguard ( $P$. persica $x P$. davidiana), a seedling rootstock, was included as a reference standard. Roostocks were always obtained from the same mother plants, free of crown gall and PRCR symptoms, in a commercial nursery. Field experiments were conducted on 2-year-old plants budded with 'Ruby Diamond' peach scion, which were grown in 100-L containers filled with unsterilized soil obtained from the Pirque soil series (Región Metropolitana, Chile), having with a clay:sand: loam proportionality of 1.5:1.4:1.0, $\mathrm{pH} 7.7$ and
$2.1 \%$ organic matter. Inoculum of P. cryptogea and A. tumefaciens was maintained on Difco corn meal agar plus antibiotics (ACMA) (Wilcox and Latorre, 2002) and on Difco nutrient agar, respectively.

\section{Crown gall assay}

Potted plants were inoculated in summer (January 2003) using $500 \mathrm{ml}$ of bacterial suspension $\left(10^{6} \mathrm{cfu} \cdot \mathrm{mL}^{-1}\right)$ of $A$. tumefaciens obtained from 4-day- old cultures on KL agar media (containing, per liter, $10 \mathrm{~g}$ lactose, $1 \mathrm{~g}$ Difco yeast extract and $12 \mathrm{~g}$ agar). The inoculum was delivered in a $15 \mathrm{~cm}$ deep hole made in the soil with the aid of knife around each rootstock. Treatments consisted of four singleplant replicates per rootstock. An equal number of wounded but noninoculated plants were left as controls. All plants were maintained under field conditions. Each inoculated and control plant was carefully pulled from the soil 20 months after inoculation, and the total number of galls on roots and the fresh weight of all galls per plant were determined.

\section{Phytophthora crown and root rot assays}

Twig assays. Detached twigs, 8 to $10 \mathrm{~cm}$ long, were taken from the mother plants of each of the tested rootstocks and used to evaluate susceptibility to $P$. cryptogea isolate DZ31 in the laboratory conditions. Five 1-yr-old twigs per rootstock were collected during winter dormancy (July) and during active seasonal growth (January) and assayed using a modification of the method of Jeffers et al. (1981). Twigs were vertically inserted in humid chambers $(16 \times 16 \times 14 \mathrm{~cm})$ containing $2 \mathrm{~cm}$ of an inoculum mixture composed, by volume, of $56 \%$ sterile vermiculite, $19 \%$ inoculum suspension (adjusted to $4-5 \times 10^{6}$ mycelial fragments $\mathrm{mL}^{-1}$ ), $14 \%$ sterile carrot broth and $11 \%$ sterile distilled water. The length of each developed canker was determined after 15 days at $20^{\circ} \mathrm{C}$. An equal number of twigs of each rootstock inserted into sterile vermiculite served as controls.

Field experiments. Actively-growing potted trees were inoculated in the spring (October), using a plug of mycelium (7 $\mathrm{mm}$ in diameter) taken from cultures of $P$. cryptogea actively growing on ACMA. Plugs were aseptically inserted underneath the cortex, at the base 
(5 $\mathrm{cm}$ above soil level) of the trunk, on the rootstock portion of the trees. The inoculated area was immediately wrapped with Parafilm tape to avoid a rapid dehydration. Plants were maintained under field conditions thereafter, and the length of the cankers and degree of gum exudation $(0=$ absence of gum, $1=$ slight exudation and $2=$ abundant exudation) were determined 73 days after inoculation. There were four single-tree replicates per rootstock. An equal number of trees, similarly injured but not inoculated, were left as controls. Reisolation of $P$. cryptogea from the resulting cankers was performed on ACMA.

In a second experiment, potted trees were inoculated early in the spring (October 2003) with $500 \mathrm{~mL}$ of a suspension of mycelial fragments of $P$. cryptogea $\left(4.5 \times 10^{6}\right.$ propagules $\cdot \mathrm{mL}^{-1}$ ) prepared from 4-5 day old cultures grown in carrot broth and comminuted in a blender (Erwin and Ribeiro, 1996). The inoculum suspension was delivered into a .15 cm deep hole excavated $12 \mathrm{~cm}$ away from each trunk, and plants were immediately irrigated. Subsequently, they were either (i) irrigated to field capacity twice a week throughout the experiment; or (ii) subjected to soil saturation episodes of either 48 or $144 \mathrm{~h}$ duration every other week, for a total of five such cycles. These plants were irrigated to field capacity between each saturation cycle. Uninoculated plants subjected to the various irrigation treatments served as controls. Root rot, reduction of root fresh weight, tree vigor and the number of dead plants for each rootstock were determined after 176 days of incubation. Root weight loss was determined by comparing the root fresh weight of each inoculated rootstock, with that of the appropriate uninoculated control. A root rot index was determined visually on a 0 to 5 scale, where $0=$ no root rot and $1=<20 \%, 2$ $=21-40 \%, 3=41-60 \%, 4=61-80 \%$ and $5=$ $>80 \%$ of the root mass rotten, respectively. Tree vigor was estimated visually on a 0 to 5 scale, where $0=$ aerial growth equivalent to that on the appropriate controls and $1=>80 \%, 2=61$ $80 \%, 3=41-60 \%, 4=21-40 \%$, and $5=<20 \%$ of the vigor obtained on the control plants, respectively. Reisolation of the causal agent was accomplished on ACMA. This experiment was repeated in the same location (Pirque, Santiago) during the following growing season as well.

\section{Statistical analyses}

The crown gall, twig assays, and crown rot inoculation experiments were designed as completely randomized experiments, replicated four times and using one plant or one twig as the experimental unit. Data were subjected to analysis of variance and means were separated according to the Duncan-Waller k-ratio t test. Data were processed using Multstat (Shane et al., 1990).

The root rot inoculation experiments were arranged in a completely randomized factorial design with four single-tree replicates per treatment. Rootstock was the main factor and saturation cycles the sub-factor. Data from the two field trials, performed in different growing seasons, were combined for analysis since variance among trials was homogeneous. Results were subjected to analysis of variance and means were separated according to Tukey (SigmaStat, Chicago, IL). The relationship between the length of the saturation cycles and root fresh weight was determined by linear regression analysis and the main rates of fresh weight loss obtained for each rootstock were compared according to Tukey (Zar, 1996).

\section{Results}

\section{Crown gall}

Tumor-like galls of ranging from 1 to $8 \mathrm{~cm}$ in diameter and from 16 to $576 \mathrm{~g}$ per plant appeared on wounded inoculated plants after 20 months of incubation. Differences among rootstocks were statistically significant $(\mathrm{p}<0.05)$ for the number of galls obtained, but not for the total weight of galls per plant. Mr.S 2/5 appeared to be the least susceptible rootstock, with a mean of only 0.3 gall per plant, whereas the other rootstocks developed 3 to 5 galls per plant and were statistically equivalent to one another (Table 1). Galls developed on injured but uninoculated plants of Cadman, but not on any other rootstocks (Table 1).

\section{Phytophthora crown and root rot}

Twig assays. Canker lesions and reddish to dark brown discoloration of inner tissues were obtained after 15 days of incubation both on 
Table 1. Number and weight of galls caused by Agrobacterium tumefaciens on inoculated and uninoculated peach rootstocks maintained for 20 months under field conditions in Pirque, Santiago.

Cuadro 1. Número y peso de las agallas producidas por Agrobacterium tumefaciens en portainjertos de durazneros inoculados y sin inocular, mantenidos por 20 meses en condiciones de campo en Pirque, Santiago.

\begin{tabular}{|c|c|c|c|c|}
\hline \multirow[t]{2}{*}{ Rootstock $^{1}$} & \multicolumn{2}{|c|}{ Inoculated } & \multicolumn{2}{|c|}{ Uninoculated } \\
\hline & No./plant & Weight $(\mathrm{g}) /$ plant & No./plant & Weight $(\mathrm{g}) /$ plant \\
\hline Cadman & $5.0 \pm 1.2 b^{2}$ & $178.3 \pm 27.8^{\mathrm{ns}}$ & $1.7 \pm 2.0 \mathrm{~b}$ & $224.3 \pm 149.4 b^{2}$ \\
\hline Mr.S 2/5 & $0.3 \pm 0.6 \mathrm{a}$ & $27.0 \pm 46.8$ & $0.0 \mathrm{a}$ & $0.0 \mathrm{a}$ \\
\hline Viking & $4.0 \pm 1.0 \mathrm{~b}$ & $73.5 \pm 38.7$ & $0.0 \mathrm{a}$ & $0.0 \mathrm{a}$ \\
\hline Nemaguard & $3.0 \pm 0.0 \mathrm{~b}$ & $221.1 \pm 308.4$ & $0.0 \mathrm{a}$ & $0.0 \mathrm{a}$ \\
\hline
\end{tabular}

${ }^{1}$ Cadman-Avimag (Prunus persica $x$ P. davidiana), Mr.S $2 / 5$ (P. cerasifera $x$ P. spinosa), Viking ([P. persica $x$ P. davidiana $] x[P$. dulcis 'Jordanolo' $x$ P. blireiana]) and Nemaguard (P. persica $x$ P. davidiana).

${ }^{2}$ Means of three replicates $( \pm$, standard deviation) not followed by a common letter are significantly different $(\mathrm{p}=0.05)$ according to DuncanWaller $\mathrm{k}$ ratio t test. ns, non significant at $\mathrm{p}<0.05$.

${ }^{\prime}$ Cadman-Avimag (Prunus persica x P. davidiana), Mr.S 2/5 (P. cerasifera x P. spinosa), Viking ([P. persica x P. davidiana] $x$ [P. dulcis 'Jordanolo' x P. blireiana/) y Nemaguard (P. persica x P. davidiana).

${ }^{2}$ Promedio de tres repeticiones $( \pm$, desviación estándar) seguidos por diferentes letras son significativamente diferentes $(p=0,05)$ según Duncan-Waller $k$ ratio t test. $n s$, no significativo a $p<0,05$.

inoculated twigs collected both during the growing season and during dormancy. The length of the cankers varied from 6.1 to 18.3 $\mathrm{mm}$ and from 18.4 to $33.7 \mathrm{~mm}$ on dormant and actively growing twigs, respectively. Differences in canker length among rootstocks were statistically significant $(\mathrm{p}<0.05)$, with Mr.S 2/5 the least susceptible to colonization by $P$. cryptogea (Figure 1). The variation in susceptibility among rootstocks was generally correlated with the results obtained following inoculations of 2-year-old trunks, with the exception of those for Mr.S2/5 (Figure 1).

Field trials. On trunks inoculated with $P$. cryptogea, canker lesions, 22.5 to132.5 mm in length, were characterized by an orange to reddish discoloration beneath the cortex. An amber-like gum exudation was also obtained on some inoculated trees, and P. cryptogea was consistently re-isolated from the cankers on each rootstock. Differences among rootstocks regarding canker length and gum exudation were statistically significant $(\mathrm{p}<0.05)$, and based on these results, Nemaguard appeared to be the least susceptible rootstock followed by Viking and Cadman, with Mr.S2/5 the most susceptible (Table 2).

When a suspension of $P$. cryptogea propagules was delivered to the root system, inoculated plants developed root rot accompanied by a substantial reduction in root mass. Also, plants exhibited general chlorosis, small leaves and reduced tree vigor (Table 2). Out of the 16 plants subjected to soil saturation treatments, seven, four, two, and zero trees died when grafted on Viking, Cadman, Nemaguard, and Mr.S2/5 rootstocks, respectively, over the 2 years, of the experiment. No trees died in the unsaturated irrigation treatment. Phytophthora cryptogea was successfully reisolated from diseased plants.

Both rootstock and soil saturation cycle had a significant effect on root rot, root fresh weight and tree vigor; however, there was no significant interaction between the two factors (Table 2). Root fresh weight declined in a linear manner in response to the length of the cyclic saturation period (x), with the loss of root fresh weight (y) described by the following equations for: Nemaguard, $\mathrm{y}=0.27+8.86, \mathrm{R}^{2}=0.96$; Viking, $\mathrm{y}=0.34 \mathrm{x}+30.31, \mathrm{R}^{2}=0.90$; Cadman, $\mathrm{y}=0.26 \mathrm{x}+27.56, \mathrm{R}^{2}=0.77$; and Mr.S 2/5, $\mathrm{y}=$ $0.34 x+17.57, R^{2}=0.96$ (Figure 2).

\section{Discussion}

For all rootstocks, symptoms that developed following inoculation of the trunk or roots with $P$. cryptogea were consistent with previous descriptions of PRCR on peach (Browne and Mircetich, 1995; Erwin and Ribeiro, 1996; Guzmán et al., 2005; Haygood et al., 1986; Kim et al., 1985; Mircetich and Keil, 1970; 
Table 2. Development of trunk lesions, gummosis, and root rot and tree dead obtained on peach rootstocks inoculated with Phytophthora cryptogea.

Cuadro 2. Desarrollo de lesiones en el tronco, gomosis, pudrición radical y muerte de portainjertos de durazneros inoculados con Phytophthora cryptogea.

\begin{tabular}{|c|c|c|c|c|c|c|}
\hline \multirow[b]{2}{*}{ Rootstock } & \multicolumn{2}{|c|}{ Trunk inoculation } & \multicolumn{4}{|c|}{ Root inoculation ${ }^{1}$} \\
\hline & $\begin{array}{c}\text { Canker length } \\
(\mathrm{mm})\end{array}$ & $\begin{array}{c}\text { Gum } \\
(0 \text { to } 2)^{2}\end{array}$ & $\begin{array}{c}\text { Root } \\
\text { Rot } \\
(0 \text { to } 5)^{3}\end{array}$ & $\begin{array}{l}\text { Loss of root } \\
\text { fresh weight } \\
\qquad \%)^{4}\end{array}$ & $\begin{array}{c}\text { Tree } \\
\text { vigor } \\
(0 \text { to } 5)^{5}\end{array}$ & $\begin{array}{l}\text { Dead trees } \\
(\mathrm{n}=48)^{6}\end{array}$ \\
\hline Cadman (C) & $47.9 \mathrm{ab}^{7}$ & $0.9 \mathrm{~b}^{7}$ & $1.6 \mathrm{~b}^{8}$ & $28.1 \mathrm{~b}^{8}$ & $1.1 \mathrm{ab}^{8}$ & $4 \mathrm{~ns}^{8}$ \\
\hline Mr.S 2/5 (M) & $106.5 \mathrm{c}$ & $1.9 \mathrm{c}$ & $0.8 \mathrm{~b}$ & $30.1 \mathrm{~b}$ & $0.6 \mathrm{~b}$ & 0 \\
\hline Viking (V) & $77.5 \mathrm{bc}$ & $0.9 \mathrm{~b}$ & $2.6 \mathrm{a}$ & $39.3 \mathrm{a}$ & $2.2 \mathrm{a}$ & 7 \\
\hline \multirow[t]{2}{*}{ Nemaguard (N) } & $28.4 \mathrm{a}$ & $0.3 \mathrm{a}$ & $2.1 \mathrm{~b}$ & $19.6 \mathrm{~b}$ & $1.3 \mathrm{ab}$ & 2 \\
\hline & & & $p$ & $p$ & $p$ & $p$ \\
\hline Soil saturation (SS & & & $<0.001$ & $<0.001$ & $<0.001$ & 0.018 \\
\hline Rootstock (R) & & & 0.003 & 0.004 & 0.005 & 0.075 \\
\hline SS x R & & & 0.071 & 0.178 & 0.675 & 0.440 \\
\hline
\end{tabular}

${ }^{1}$ Means of two trials performed in the same locations during two consecutive growing seasons were combined for analysis since variance among trials was homogeneous.

${ }^{2}$ Gum exudation where $0=$ absence of gum exudation, $1=$ slight exudation and $2=$ abundant exudation.

${ }^{3}$ Root rot index was determined in a 0 to 5 scale, where $0=$ healthy plants; diseased plants with $1=1-20,2=21-40,3=41-60,4=61-80$, and $5=>80 \%$ of the root mass rotten.

${ }^{4}$ Root weight loss was determined by comparing the root fresh weight of each inoculated rootstock with that for the appropriate uninoculated control treatment.

${ }^{5}$ Tree vigor was estimated in a 0 to 5 scale where $0=$ aerial development obtained on uninoculated controls; $1=>80 \%, 2=61-80 \%, 3=41-60 \%$, $4=21-40 \%$, and $5=<20 \%$ of the vigor obtained on uninoculated controls.

${ }^{6}$ Number of dead plants out of 48 plants per each rootstock.

${ }^{7}$ Means (of four replicates) in a column not followed by a common letter are significantly different $(\mathrm{p}=0.05)$ according to Duncan-Waller k-ratio t test.

${ }^{8}$ Means within a column not followed by a common letter are significantly different $(\mathrm{p}=0.05)$ according to Tukey test. Percentages were transformed to $\arcsin \operatorname{sqrt}(\mathrm{x})$ before analysis of variance, but non transformed data are presented. ns, statistically non significant at $\mathrm{p}<$ 0.05 .

${ }^{1}$ Promedios de dos ensayos realizados en la misma localidad, en dos años consecutivos, los que se combinaron para realizar el análisis debido a que la varianza entre los ensayos fue homogénea.

${ }^{2}$ Exudación gomosa donde $0=$ ausencia de exudación gomosa, $1=$ escasa exudación y $2=$ abundante exudación.

${ }^{3}$ Indice de pudrición radical determinado en una escala de 0 a 5, donde $0=$ plantas sanas; $1=1-20,2=21-40,3=41-60,4=61-80$, y $5=>80 \%$ de la masa radical podrida .

${ }^{4}$ Pérdida de peso radical determinada comparando el peso radical fresco de cada portainjerto inoculado con relación al mismo portainjerto sin inocular.

${ }^{5}$ Vigor del árbol estimado en escala de 0 a 5 , donde $0=$ desarrollo aéreo obtenido con árboles testigos no inoculados; $1=>80 \%, 2=61-80 \%$, $3=41-60 \%, 4=21-40 \%$, y $5=<20 \%$ vigor obtenido en árboles inoculados.

${ }^{6}$ Número de plantas muertas sobre 48 plantas por portainjerto.

${ }^{7}$ Promedios (de cuatro repeticiones) seguidos por distinta letra en una misma columna son significativamente diferentes $(p=0,05)$ según Duncan-Waller k-ratio t test.

${ }^{8}$ Promedios dentro de una columna seguido por distinta letra son significativamente diferentes $(p=0,05)$ según Tukey. Los porcentajes fueron transformados a arcoseno raíz cuadrada de $x$, antes del análisis de varianza, pero se presentan valores sin transformar. $n s$, estadísticamente no significativo a $p<0,05$.

Thomidis, 2000a,b; Wilcox and Ellis, 1989; Wilcox and Latorre, 2002). Trunk inoculation resulted in canker and gummosis with reddish necrotic tissues underneath the bark. Root inoculation induced root rot associated with foliar chlorosis, lack of vigor, dieback, and even mortality in severe cases. In contrast, no aerial symptoms were observed on crown gall infected plants after 20 months of incubation.
Resistant rootstocks should play an important role in integrated management approaches to control crown gall and PRCR in peach orchards. Based on our results, Mr.S 2/5, a rootstock clonally propagated, was highly resistant to A. tumefaciens and therefore, it would be a promising alternative to control crown gall, especially in heavily infested soils. However, resistance to crown gall may be 


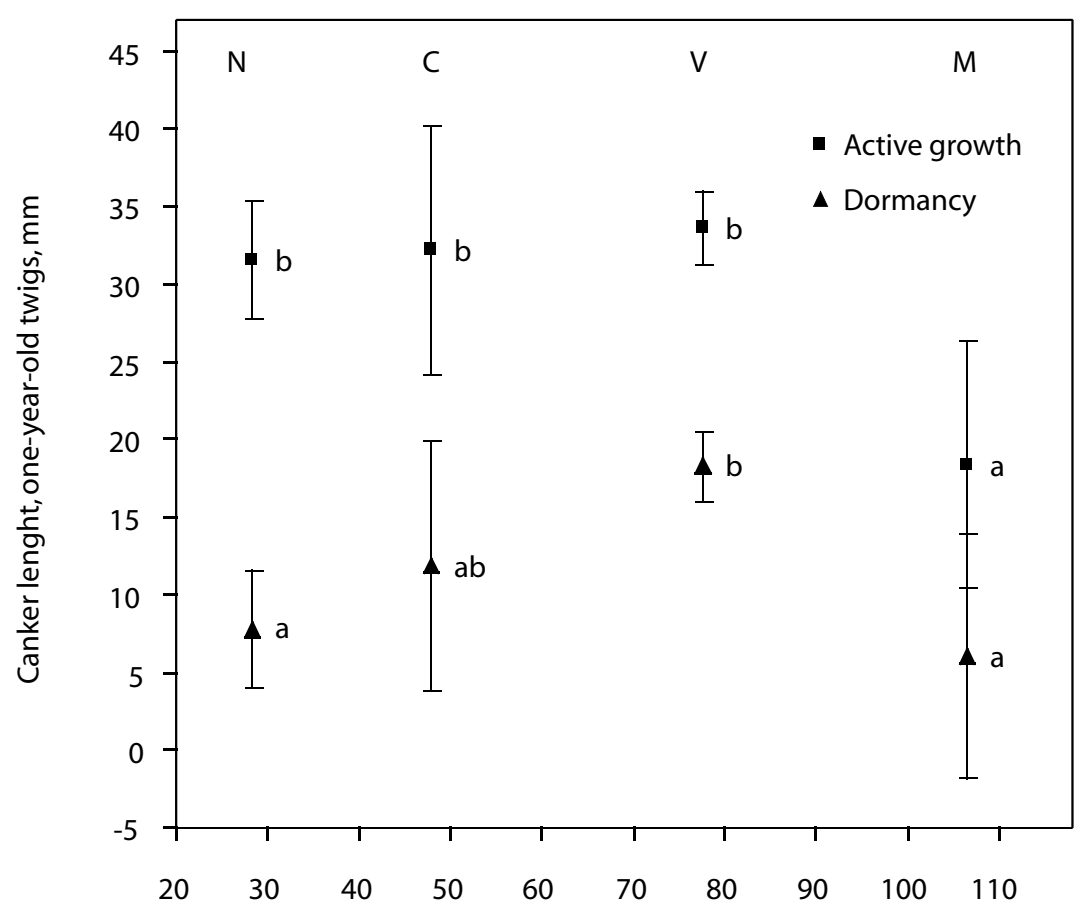

Canker lenght, 2-year-old trunk, mm

Figure 1. Relationship between canker length obtained on detached twigs and those on on 2-year-old trunks of each of the tested peach rootstocks following inoculation with Phytophthora cryptogea $(\mathrm{N}=$ Nemaguard, $\mathrm{C}=\mathrm{Cadman}-\mathrm{Avimag}$, $\mathrm{V}=$ Viking and $\mathrm{M}=\mathrm{Mr} . \mathrm{S} 2 / 5)$. One-yr-old twigs, 8 to $10 \mathrm{~cm}$ long, were collected during dormancy (July) and during the growing season (January), from the same mother plants. For each inoculation timing, means of four replicates followed by different letters were significantly different, among rootstocks, according to Duncan-Waller $\mathrm{k}$ ratio $\mathrm{t}$ test $(\mathrm{p}=0.05)$. Bars $=$ standard deviation.

Figura 1. Relación entre el largo del cancro obtenido en ramillas cortadas y aquellos desarrollados en troncos de dos años de cada uno de los portainjertos de duraznero estudiados e inoculados con Phytophthora cryptogea $(N=N e m a g u a r d$, $C=$ Cadman-Avimag, $V=$ Viking and $M=M r . S 2 / 5)$. Ramillas de un año de edad de 8 a $10 \mathrm{~cm}$ de largo, se recolectaron durante el letargo (julio) y durante la estación de crecimiento (enero), desde la misma planta madre. Para cada fecha de inoculación, los promedios de cuatro repeticiones seguidos por diferentes letras fueron significativamente diferentes, entre portainjertos, según Duncan-Waller k ratio t test $(p=0,05)$. Barras = desviación estándar.

strain dependent (Bliss et al., 1999), hence the results of this study require further validation with additional Chilean strains of the pathogen before final conclusions are established. Nevertheless, similar results were reported in Italy, where Mr.S 2/5 was almost insensitive to a large number of strains of A. tumefaciens (Zoina and Raio, 1999). In our study, Viking and Nemaguard displayed a high level of sensitivity to crown gall, and Cadman appeared to be the most susceptible rootstock, developing a significant number of galls even in natural soil conditions, where the inoculum concentration was presumed to be low. It is important to state that the high variability obtained in the average weight of the gall per plant was mainly due to pronounced differences in the sizes of individual galls, which may have been caused by variable dates of actual infection. Therefore, we believe that total gall weight per plant remains a useful parameter to test for crown gall susceptibility, even though differences among rootstocks were not statistically significant in this study. 
Coincident with several reports that have demonstrated that the extent of canker lesions produced by $P$. cryptogea and other Phytophthora spp. fluctuate during the growing season, the extent of the canker lesions produced by $P$. cryptogea on excised twigs of each rootstock during dormancy (winter) was considerably lower than the extent of the cankers that developed on actively growing twigs (summer). These differences can at least partially be attributed to differences in the degree on colonization of $P$. cryptogea associated with the nutritional status of the stem tissue used in these bioassays (Jeffers and Aldwinckle,1986; Matheron. and Matejka, 1989, 1993; Matheron and Mircetich 1985b; Sewell and Wilson, 1973; Thomidis, 2000a).

Similar to other reports (Flores and Hindal, 1983; Jeffers et al., 1981; Matheron and Mircetich, 1985b; Utkhede and Quame, 1988), but with the exception of Mr.S 2/5, the relative susceptibility to $P$. cryptogea of each of the tested peach rootstocks as determined by the excised-stem assay was correlated with the relative susceptibility determined by trunk inoculation of 2-year-old plants in the field. In agreement with previous studies on apple (Utkhede and Quamme, 1988), the best relationship between the excised-stem assay and canker length on 2-year-old plants was obtained when peach rootstock twigs were collected during dormancy. During the summer, $P$. cryptogea appears to overwhelm the resistance of actively growing stems (Figure 1). Therefore, the excised-stem assay on dormant twigs appears to be a useful tool for an initial susceptibility screening of peach rootstocks, but cautious conclusions should always be taken, considering that results obtained in the laboratory were not always correlated with results obtained in field tests. Furthermore, the inoculum concentration used in laboratory tests may not reflect the inoculum pressure under field conditions, and this test (as well as our trunk inoculation assay) involved wounding of the bark prior to challenge with the pathogen. Therefore, it is also possible that potential resistance mechanisms associated with the bark might be negated.

For all rootstocks, disease severity caused by $P$. cryptogea was clearly proportional to the duration of the cyclic soil saturation episodes (Figure 2). A similar relationship has been reported for P. cryptogea and other Phytophthora spp. on other crops. Flooding can increase disease severity by a reduction of the host resistance to colonization by Phytophthora spp., by promoting inoculum production, and by enhancing zoospore discharge and dispersal (Blaker and MacDonald, 1981; Browne and Mircetich, 1988; Duncan and Kennedy, 1989; Kuan and Erwin, 1980; MacDonald and Dunniway, 1978; Matheron and Mircetich, 1985a; Wilcox and Mircetich, 1985a, b).

Although Mr.S 2/5 showed the greatest degree of colonization by $P$. cryptogea following trunk inoculations, it was relatively resistant to root rot development following soil inoculation, which more closely reflects natural host-pathogen interactions in the field. Therefore, these results suggest that susceptibly to crown colonization and root rot are not necessarily correlated, as has previously been demonstrated on other fruit crops (Matheron et al., 1998).

In conclusion, the results obtained in this study demonstrated that Mr.S 2/5 was highly resistant and Cadman the least resistant rootstock to $A$. tumefaciens. Our results showed that Mr.S $2 / 5$ is relatively resistant to root rot caused by $P$. cryptogea, which is the most common Phytophthora species presently found on peach trees in Chile. For all rootstocks, PRCR severity increased considerably after repeated soil saturation episodes, and the loss of root mass increased in a linear manner as the saturation periods increased from 0 to $144 \mathrm{~h}$.

\section{Resumen}

Las agallas de la corona (Agrobacterium tumefaciens) y la pudrición radical y del cuello causada por Phytophthora cryptogea, son dos factores que limitan considerablemente la producción de durazneros (Prunus persica) en Chile. Actualmente, Nemaguard es el principal portainjerto en huertos de durazneros. Existen varios portainjertos clonales en desarrollo a nivel mundial. Sin embargo, la información existente respecto de la susceptibilidad de estos portainjertos a las agallas de la corona y a la 


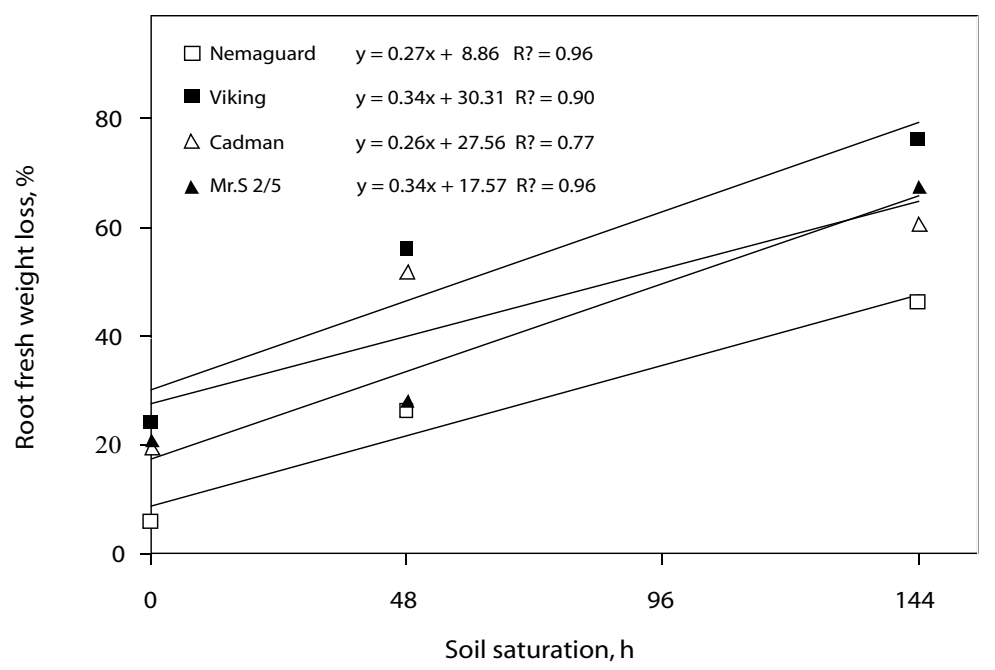

Figure 2. Relationship between soil saturation cycles and root fresh weight loss caused by Phytophthora cryptogea on peach roostocks. Each value is the mean of two trials conducted under similar experimental conditions.

Figura 2. Relación entre los ciclos de saturación del suelo y la pérdida de peso radical fresco causado por Phytophthora cryptogea en portainjertos de durazneros. Cada valor es el promedio de dos ensayos conducidos en similares condiciones experimentales.

pudrición radical y del cuello es limitada. Por lo tanto, esta investigación tuvo por objetivo estudiar la susceptibilidad a A. tumefaciens y $P$. cryptogea de los portainjertos clonales Cadman ${ }^{\circledR}$-Avimag (P. persica $x$ P. davidiana), Mr.S 2/5 (P. cerasifera $x$ P. spinosa) y Viking $([P$. persica $x$. davidiana $] \quad x \quad[P$. dulcis 'Jordanolo' $x$ P. blireiana]). Como estándar se incluyó Nemaguard (P. persica $x$ P. davidiana), portainjerto de semilla. De acuerdo con los resultados obtenidos, Mr.S 2/5 fue altamente resistente a $A$. tumefaciens. Las diferencias obtenidas entre Nemaguard, Viking y Cadman, luego de 20 meses en suelo artificialmente infectado, no fueron estadísticamente significativas. No obstante, Cadman fue el único que desarrolló agallas en un suelo naturalmente infectado. El largo de los cancros desarrollados por $P$. cryptogea en ramillas cortadas fue mayor en ramillas en crecimiento activo que en ramillas obtenidas durante el letargo invernal. Las diferencias entre portainjertos obtenidas en ramillas en letargo se correlacionaron con los resultados obtenidos en inoculaciones realizadas en plantas de dos años de edad, injertadas con duraznero 'Ruby Diamond'. Para todos los portinjertos, la severidad de la pudrición radical aumentó considerablemente luego de repetidos eventos de saturación del suelo. La pérdida de masa radical aumentó linealmente al aumentar la saturación del suelo entre 0 y 144 h. Los resultados obtenidos demuestran que Mr.S 2/5 es relativamente resistente a la pudrición de raíces causada por $P$. cryptogea que es la principal especies de Phytophthora descrita en duraznero en Chile.

Palabras clave: Agrobacterium tumefaciens, enfermedades del duraznero, nectarines, Phytophthora cryptogea, portainjertos resistentes, Prunus spp.

\section{Acknowledgements}

The authors are gratefully for the financial support received from FDI, CORFO project 00C7AT-12 and FONDECYT 1951025. The authors would like to thank Univiveros (Chile) and Viveros Requinoa (Chile) for providing the plant material used in this study. 


\section{References}

Blaker, N.S., and J.D. MacDonald. 1981. Predisposing effect of soil moisture extremes on the susceptibility of rhododendron to Phytophthora root and crown rot. Phytopathology 71:831834.

Bliss, F.A., A.A. Almehdi, A.M. Dandekar, P.L. Schuerman, and N. Bellaloui.1999. Crown gall resistance in accessions of 20 Prunus species. Hortscience 34: 326-330.

Browne, G.T., and S.M. Mircetich.1988. Effects of flood duration on the development of Phytophthora root and crown rots of apple. Phytopathology 78:846-851.

Browne, G.T., and S.M. Mircetich. 1995. Phytophthora Root and Crown Rots. In: Compendium of Stone Fruits Disease. J.M Ogawa, E.I. Zehr, G.W. Bird, D.F. Ritchie, K. Uriu, and J.K. Uyemoto (eds.). The American Phytopathological Society, St. Paul MN. 98 pp.

Dozier, W.A. Jr., J.W. Knowles, C.C. Carlton, R.C. Rom, E.H. Arrington, E.J. Wehunt, U.L. Yadava, S.L. Doud, D.F. Ritchie, C.C. Clayton, E.I. Zehr, C.E. Gambrell, J.A. Britt, and D.W. Lockwood. 1984. Survival, growth and yield of peach trees as affected by rootstocks. HortScience 19:26-30.

Duncan, J.M., and D.M. Kennedy. 1989. The effect of waterlogging on Phytophthora root rot of red raspberry. Plant Pathology 38:161-168.

Erwin, D.C., and O.K. Ribeiro. 1996. Phytophthora Diseases Worldwide. The American Phytopathological Society. St. Paul, MN. 562 pp.

Flores, S.E., and D.F. Hindal. 1983. In vitro twig assay with Phytophthora species on peach. Phytopathology 73:965 (Abstract).

Guzmán, G., B.A. Latorre, and W.F. Wilcox. 2005. First report of Phytophthora cryptogea root and crown rot on peach trees in Chile. Plant Disease 89:1010-1010.

Haygood, R.A., C.H. Graves, and W.H. Ridings. 1986. Phytophthora root rot and stem canker of peach trees in Mississipi. Plant Disease 70:866868.

Jeffers, S.N., and H.S. Aldwinckle. 1986. Seasonal variation in extent and colonization of two apple rootstocks by five species of Phytophthora. Plant Disease 70:941-945.

Jeffers, S.N., H.S. Aldwinckle, T.J. Burr, and P.A. Arneson.1981. Excised twig assay for the study of apple tree crown rot pathogens in vitro. Plant Disease 65:823-825.

Kim, S.H., J.F. D’Amico, and B.A. Jafee. 1985. Association of Phytophthora cryptogea with peach collar rot in Pennsylvania. Phytopathology
75:626. (Abstract).

Kuan, T.L., and D.C. Erwin. 1980. Predisposition effect of water saturation of soil on Phytophthora root rot of alfalfa. Phytopathology 70:981-986.

Latorre, B.A. 2004. Enfermedades de las Plantas Cultivadas. Sixth ed. Ediciones Universidad Católica de Chile. Santiago, Chile. 638 pp.

MacDonald, J.D., and J.M. Duniway. 1978. Influence of the matric and osmotic components of water potential on zoospore discharge in Phytophthora. Phytopathology 68:751-757.

Matheron, M.E., and J.C. Matejka. 1989. Temporal changes in susceptibility of citrus phloem tissue to colonization of Phytophthora citrophthora and $P$. parasitica. Plant Disease 73:408-411.

Matheron, M.E., and J.C. Matejka. 1993. Seasonal differences in susceptibility of three citrus rootstocks to root lesions caused by Phytophthora citrophthora and P. parasitica. Plant Disease 77:729-732.

Matheron, M.E., and S.M. Mircetich. 1985a. Influence of flooding duration on development of Phytophthora root and crown rot of Junglans hindsii and Paradox walnut root-stocks. Phytopathology 75:973-976.

Matheron, M.E., and S.M. Mircetich. 1985b. Seasonal variation in susceptibility of Juglands hindisii and Paradox rootstocks of English walnut trees to Phytophthora citricola. Phytopathology 75:970-972.

Matheron, M., G. Wright, and M. Porchas. 1998. Resistance to Phytophthora citrophthora and $P$. parasitica and nursery characteristic of several citrus rootstocks. Plant Disease 82: 1217-1225.

Mircetich, S.M., and H.L. Keil. 1970. Phytophthora cinnamomi root rot and stem canker of peach trees. Phytopathology 60:1376-1382.

Novoa, R., and S. Villaseca (eds.) 1989. Mapa Agroclimático de Chile. Instituto de Investigaciones Agropecuarias. Ministerio de Agricultura. Santiago, Chile. 221 pp.

Renaud, R., R. Bernhard, C. Grasselly, and F. Dosba. 1988. Diploid plum x peach hybrid rootstocks for stone fruit trees. HortScience 23:115-116.

Rom, C., and R. Carlson. 1989. Rooststocks for Fruits Crops. Academic Press, London, UK. $377 \mathrm{pp}$.

Shane, W.W., J.G. Joyner, and C.C. Powell 1990. Applical, Randoma and Multstat the microcomputer utilities for managing field trial experiments. Plant Disease 74:333-334.

Sewell, G.W.F., and J.F. Wilson. 1973. Phytophthora collar rot of apple: Seasonal effects on infections and disease development. Ann. Appl. Biol. 74:149-158.

Thomidis, T. 2000a. Seasonal variation in crown rot of GF677 and KID I peach rootstocks by 
Phytophthora cactorum, $P$. citrophthora and $P$. syringae. Phytopathol. Mediterr. 39:396-403.

Thomidis, T. 2000b. Field susceptibility of four peach rootstocks to Phytophthora citrophthora and $P$. syringae. Phytopathol. Mediterr. 39:404409.

Utkhede, R.S., and H.A. Quame. 1988. Use of the excised shoot assay to evaluate resistance to Phytophthora cactorum of apple rootstock cultivars. Canadian Journal Plant Science 68:851-857.

Wilcox, W.F., and M.A. Ellis. 1989. Phytophthora root and crown rots of peach trees in the Eastern Great Lakes Region. Plant Disease 73:794-797.

Wilcox, W.F., and B.A. Latorre. 2002. Identities and geographic distributions of Phytophthora spp. causing root rot of red raspberry in Chile. Plant Disease 86:1357-1362.

Wilcox, W.F., and S.M. Mircetich. 1985a. Effects of flooding duration on the development of Phytophthora root and crown rots of cherry. Phytopathology 75:1451-1455.

Wilcox, W.F., and S.M. Mircetich. 1985b. Influence of soil water matric potential on the development of Phytophthora root and crown rots of cherry. Phytopathology 75:648-653.

Zar, J. 1996. Bioestatistical Analysis. Third ed. Prentice Hall, New Jersey, USA. 662 pp.

Zoina, A., and A. Raio. 1999. Susceptibility of some peach rootstocks to crown gall. Journal of Plant Pathology 81:181-187. 